\title{
The analysis of the influence of the corrosion protection method of selected steel elements on the steel structure life cycle costs
}

\author{
Adam Kristowski $^{{ }^{*}}$, Beata Grzyl ${ }^{\mathrm{a}}$, Dariusz Kowalski ${ }^{\mathrm{a}}$ \\ ${ }^{a}$ Gdansk University of Technology, Faculty of Civil and Environmental Engineering, Narutowicza 11/12 Str., 80-233 Gdansk, Poland
}

\begin{abstract}
Steel products are widely used in the construction for the performance of essential and additional elements of engineering structures. They are characterized by high tensile strength, compression and bending, the structure homogeneity, the possibility of assembly regardless of the season and climatic conditions, ease of processing and the possibility of almost any shape. The main disadvantage of steel structures is their high susceptibility to corrosion, which depends on local operating conditions and the type of applied corrosion protection system.

The aim of the research carried out by the authors is to indicate the possibility of reducing the costs associated with anti-corrosion protection, incurred at the stage of operation of the steel structure over a period of several decades. The scope of the research includes the life cycle cost analysis for selected steel elements using three alternative corrosion protection systems.

The subject of the research is the analysis of the influence of the corrosion protection method of selected steel constructions on its life cycle costs.

On the chosen example of the selected object and problems related to its use and maintenance, the possibility of using a singlelayer protection in the form of a metallization coating made in a hot-dip galvanizing process, a three-layer varnish coating based on liquid paints and protection composed of a galvanized metallization coating and a two-layer paint coating is considered. The assessment is carried out in accordance with the life-cycle cost estimation algorithm (LCC).
\end{abstract}

(C) 2018 The Authors. Published by Diamond Congress Ltd., Budapest University of Technology and Economics Peer-review under responsibility of the scientific committee of the Creative Construction Conference 2018.

Keywords: steel construction; steel protection; life cycle cost; anti-corrosion protection; corrosion;

\section{Introduction - anti-corrosion protection systems}

Analyzing the advantages and disadvantages of the corrosion-resistant coatings that can be applied in practice, protecting steel components of engineering structures, their durability, full protection against corrosion and economic considerations should be taken into account. It is important to compare the costs incurred at the stage of assembling the elements and making the protective coating with the costs generated during their maintenance and use. The total life cycle cost of a given corrosion protection system includes the cost of its implementation as well as the costs of renewals, regenerations, repairs (within a defined range) and re-implementation (to the full extent). Table 1 presents an example comparison of protection in the form of hot dip galvanizing with two painting systems. The paint systems adopted for the analysis differ in terms of the preparation of the steel surface and application of the coating material, which corresponds to two conditions for the preparatory work and the estimated durability of the systems over time. 
Table 1. The comparison of the essential features of anticorrosion protection in the form of a galvanized layer and paint coatings

\begin{tabular}{llll}
\hline Operation & Hot dip galvanizing & Painting system 1 & Painting system 2 \\
\hline surface preparation & $\begin{array}{l}\text { chemical treatment included in } \\
\text { the price }\end{array}$ & $\begin{array}{l}\text { abrasive blasting mechanical } \\
\text { treatment }\end{array}$ & manual \\
\hline priming coat & - & 1 & 1 \\
\hline topcoat & zinc, $85 \mu \mathrm{m}$ & 2 & 2 \\
\hline durability & 50 years & 11 years & 8 years \\
\hline repair & - & over periods of 11 years & Over periods of 8 years \\
\hline $\begin{array}{l}\text { implementation } \\
\text { and repairs costs in [\%] }\end{array}$ & 100 & 169 & 198 \\
\hline source: $[1]$ & & & \\
\hline
\end{tabular}

Analyzing the total life cycle costs of a given type of corrosion protection, generated in the long-term perspective (e.g. 50 years) should be considered in the aspect of durability of structure corrosion protection (Figure 1).

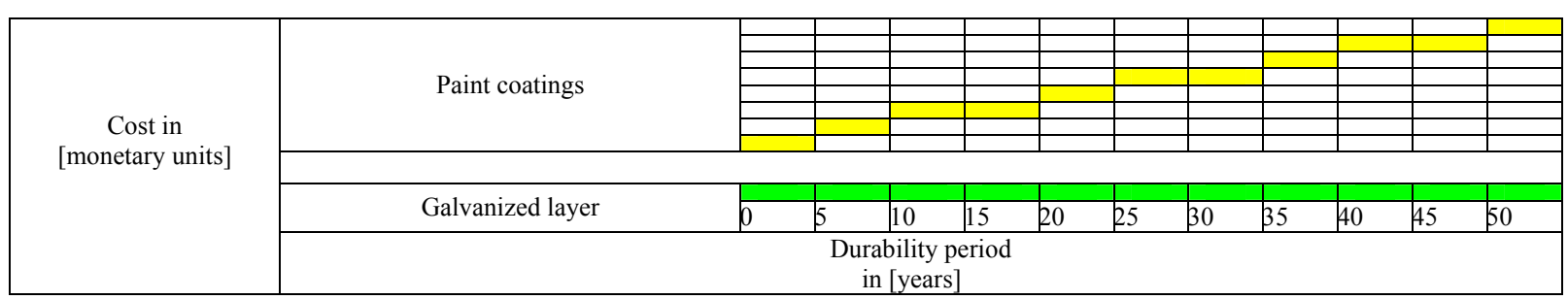

Fig. 1 Costs for maintaining the durability of anti-corrosion protection in the form of paint coatings and a galvanized layer source: own study based on [1]

The fast aging time, loss of elasticity, cracking and scratching of paint coatings, which constitute anti-corrosion protection of the steel structure, consequently contribute to a significant reduction of its durability (Figure 2).

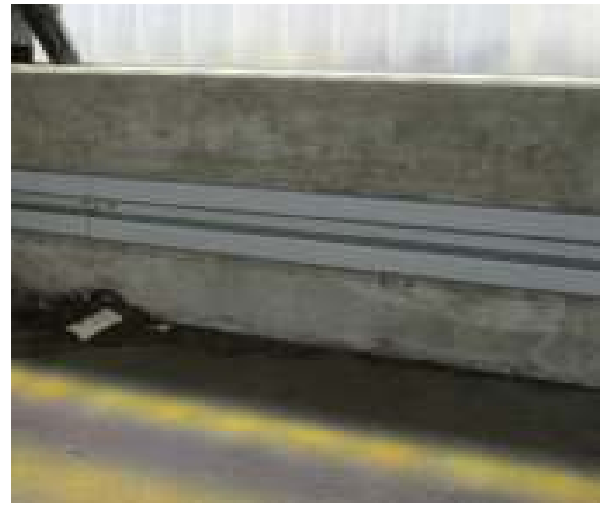

a)

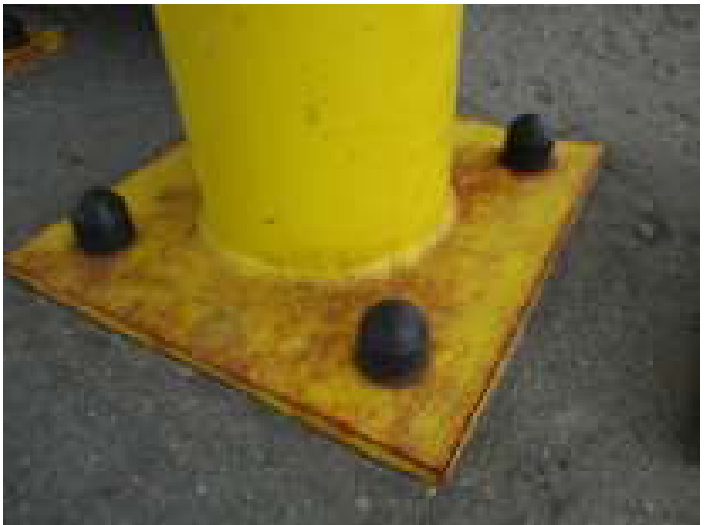

b)

Fig. 2. The protection ofobject elements applied on one object

a) galvanized steel barrier, b) protective pillar

The need to repeat every few years the labor-intensive and costly maintenance and repair procedures causes that the costs of this type of protection increase over time (Figure 1). The cost of protecting the steel structure in the form of a galvanized layer remains for a longer period, and in principle the whole period of use at a constant level, which is caused by the lack of treatments related to its renewal and repair. From the user's point of view, it is also important to maintain the steel structure in a proper technical and aesthetic condition. Renovation of paint coatings of steel supporting or auxiliary structures in the operated facility is often associated with numerous technological and organizational difficulties. A serious problem is the proper preparation of the construction surface for painting and the application of a new coating on the element entire surface. Therefore, it is important to design and manufacture anti-corrosion coatings in order to make them stable for long life, when only temporary repairs of local damage are made [2].

Attention should also be paid to the level and quality of information contained in design and technological studies for 
the structures being made. They should also apply to adequate corrosion protection.

An important issue related to the selection of a given type of corrosion protection of a steel structure is also its impact on the natural environment, health and safety conditions and hazards during the application of protective coatings [3].

At the design stage, the type of applied anticorrosion protection system should be analyzed in the context of its suitability, the possibility of maintenance $[4,5]$ and the impact on the environment. The use of liquid anticorrosive materials for the production of protective and decorative coatings is associated with the emission of significant amounts of volatile organic compounds VOC into the environment, whose source are all auxiliary preparations applied in preparatory works in the form of solvents, removers and as liquid paints used to make coatings. Depending on the type of film-forming material, the amount of organic volatile compounds contained in paint products ranges from 250 - 850 grams/liter of products in a ready-to-use state. During the process of binding coatings, these compounds evaporate into the environment, which contributes to both local and cross-border formation of photochemical oxidants in the tropospheric boundary layer by ozone formation, as well as to the development of asthmatic diseases in people exposed to them $[6,7,8]$.

\section{The life cycle cost}

The life cycle cost estimation (LCC) is an economic analysis process aimed at assessing the total cost of acquisition, possession and liquidation of a product (construction, facility) [9, 10]. In broad terms, the analysis provides important data relevant to the design, development, use and disposal of the product (construction, facility). The estimating of life cycle costs can also be effectively applied to the assessment of costs associated with specific activities, e.g. to assess the results of various methods of operating products, structures, objects [11].

The lifecycle cost of steel elements protected against corrosion by a specific technology, their lifetime and reliability depend on many factors. These include the scope and detail of the technical design, the quality of construction and assembly of the structure, the scope and the possibility of carrying out work related to its maintenance and operation. The authors look for connections between decisions made at the planning and design stage and costs incurred at the stage of maintenance and use of steel constructions.

\section{The analysis of cost of the steel construction in the aspect of three selected anti-corrosion protection systems}

The article takes into consideration protection of steel elements using three alternative coating systems for corrosion protection:

- the metallization coating with a thickness of approximately $85 \mu \mathrm{m}$ made in the process of hot dip galvanizing method - system I,

- the three-layer paint coating made on the basis of liquid paints with a total thickness adapted to the corrosive conditions of the operating environment - system II,

- the double protection consisting of a zinc metallization coating with a thickness of approximately $85 \mu \mathrm{m}$ and a double-layer paint coating with a thickness of approximately $150 \mu \mathrm{m}$, which acts as an additional corrosion protection system for the galvanized coating and provides appropriate color values of the structure - system III.

According to the assumption adopted at the design stage, all proposed corrosion protection systems should meet the protective requirements for more than 15 years, and protected steel elements should ensure safe operating conditions for at least $40-50$ years, i.e. the planned lifetime of the object.

In order to determine the initial and maintenance costs for each of the three proposed anti-corrosion systems, the authors made an analysis, which results are presented in the following chapter. The following assumptions were adopted: the steel structure service lifetime assumed for analysis - 30 years, the discount rate - $1.75 \%$, for system II and III every 5 years, on the $5 \%$ of the construction area are performed works related to cleaning, repair and renewal of anti-corrosion coatings (cleaning jet, washing, degreasing, painting), every 15 years on $20 \%$ of the steel construction area are performed works related to stream cleaning, washing, degreasing and painting, every 15 years on $100 \%$ of the surface are performed works related to painting the topcoat. The current market prices of materials and information obtained from steel structures users were applied. 
From the user's point of view, it is important to determine the initial costs, including the cost of the steel structure, its assembly and protection in the form of a protective coating (Figure 3).

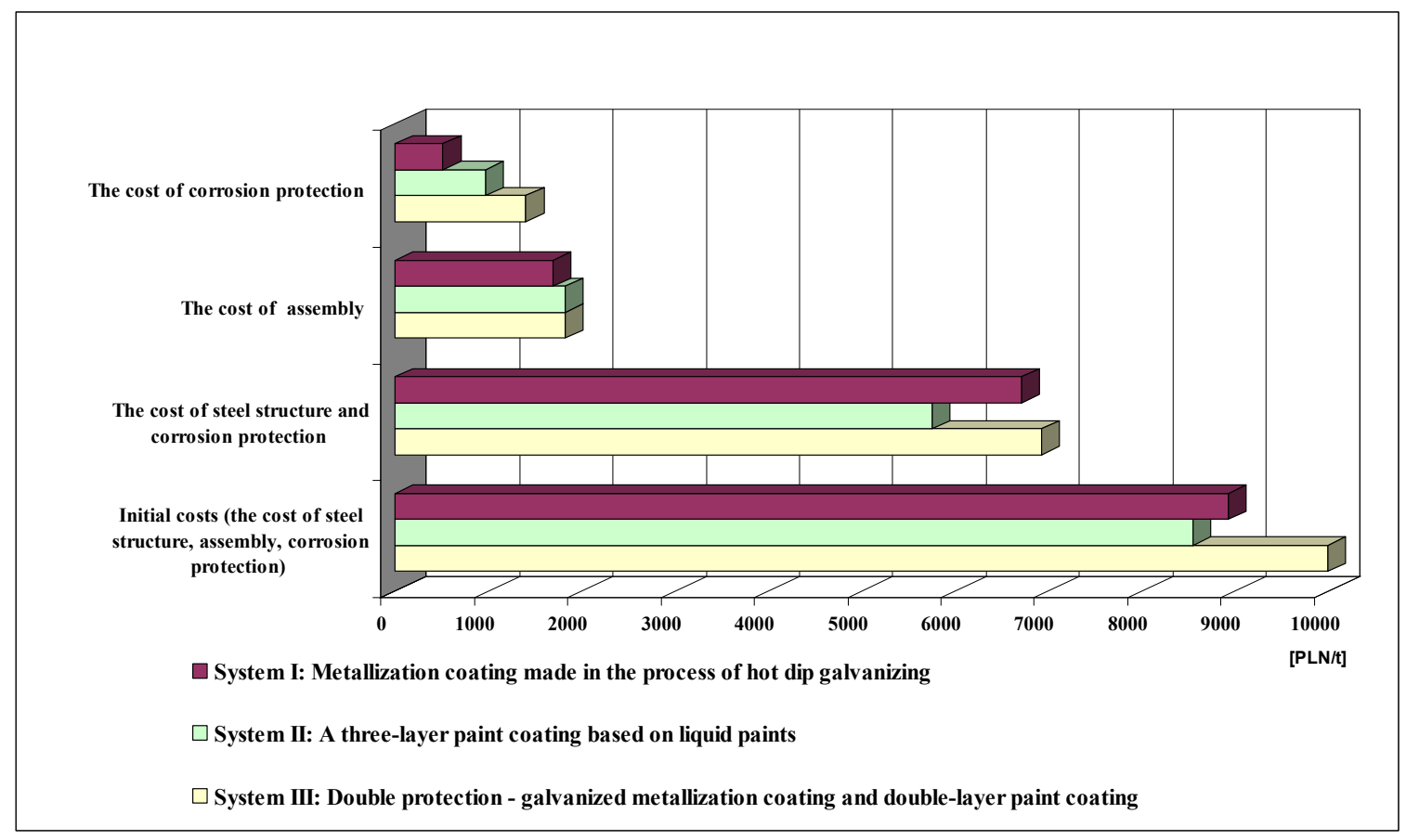

Fig. 3 Initial costs (the cost of steel structure, assembly, corrosion protection) for three corrosion protection systems for steel structure: source: own study

It is also important to compare the initial costs with the costs generated during the steel structure lifetime (Figure 4). These expenses result from running, at specified intervals, renewal, recovery, repair and protection works, but also the re-implementation of the protection in the full scope (Figure 5).

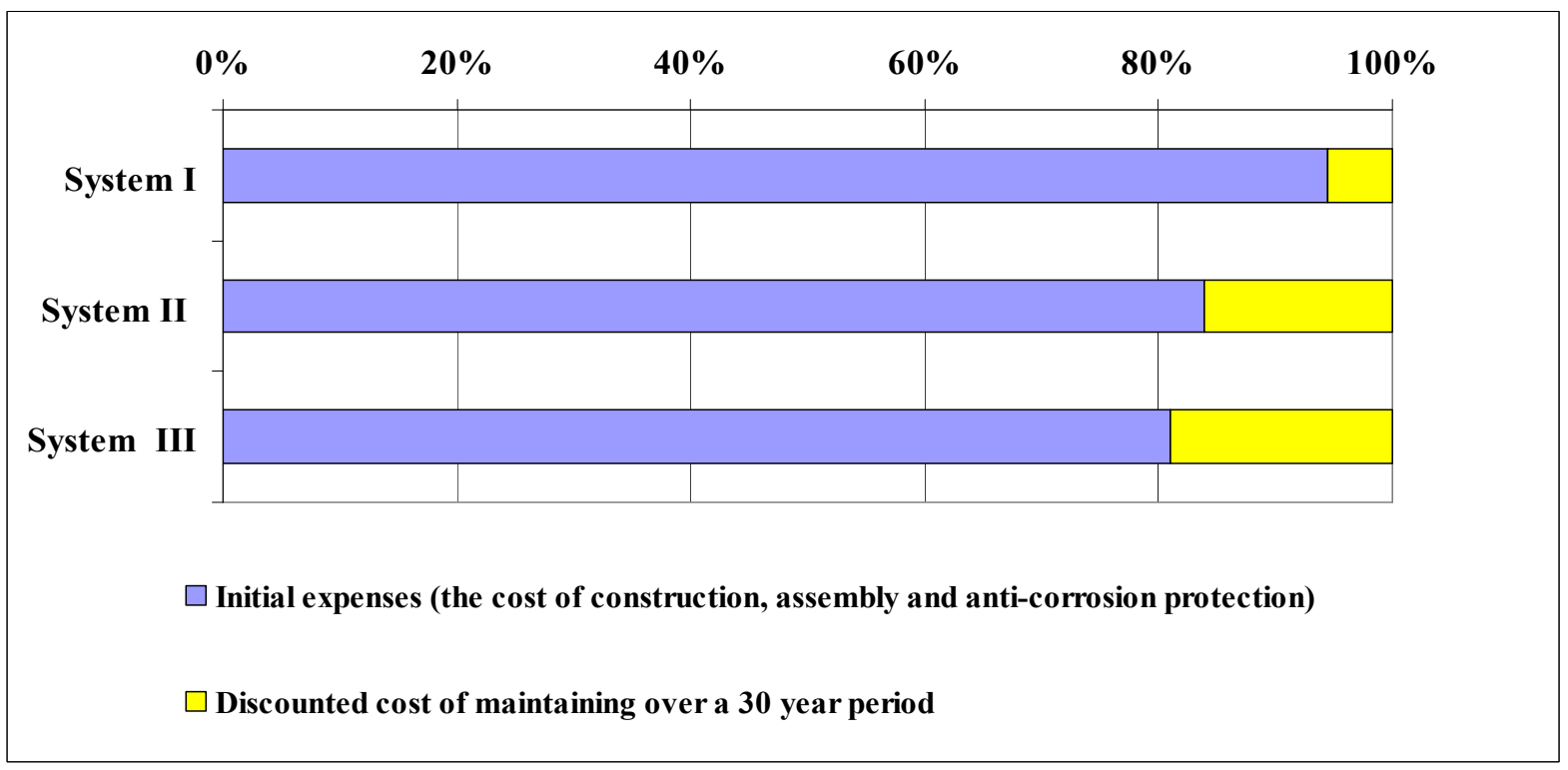

Fig. 4. Total costs (initial expenses and discounted maintenance costs of the structure) incurred over a 30 year period 


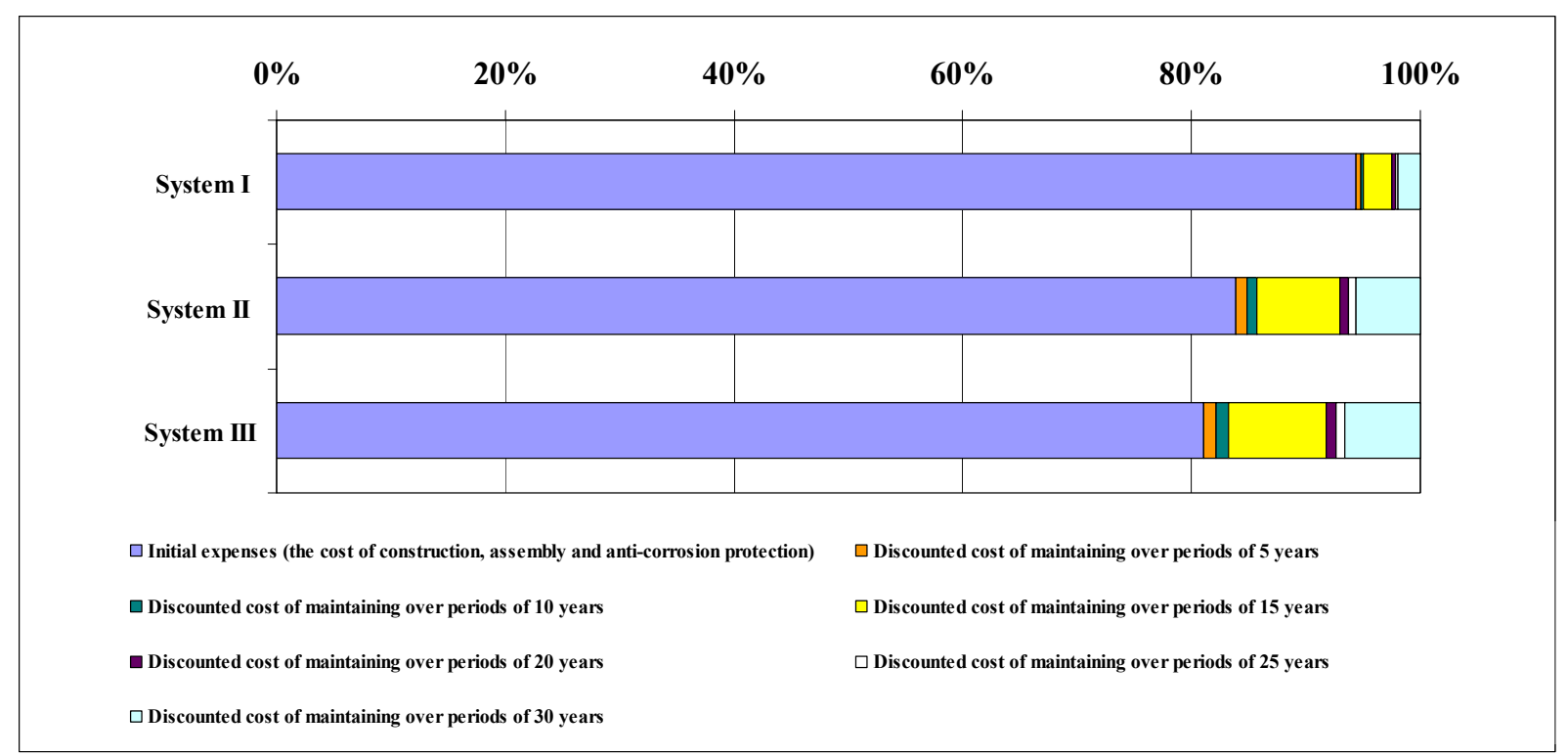

Fig. 5 Detailed total costs (initial expenses, discounted costs of structure maintenance and cleaning) incurred over a 30 year period

In the light of the above analyzes, it can be concluded that taking into account only the initial cost (Figure 3), the most expensive anti-corrosion protection is system II, followed by the I and III. Taking into account the discounted costs of maintaining the steel structure in 30 years, protected against corrosion according to the proposed technology - the most expensive solution is system III, followed by II and I. It can be concluded that in the long term, anticorrosion protection in the form of paint coatings (system III and II ) are more expensive solutions. The fast aging process of painting protective coatings, loss of elasticity, scratches, cracks and flaking result in a significant reduction of their durability with the passage of time.

In practice, this means that every 5 - 8 years must be repeated labor-intensive and costly process of maintenance and repair in the form of applying new paint coatings. The use of steel structure protection system in the form of a galvanized layer, in the course of operation, does not require the need to undertake costly maintenance activities. When assessing the total life-cycle cost, i.e. the initial effort and the 30-year maintenance period of the steel structure protected in the three analyzed systems, it can be concluded that the cheapest solution is system I - steel structure protected with a metallization coating made in the hot dip galvanizing process, and anti-corrosion protection in the form of anti-corrosive painting coatings made on non-galvanized and galvanized steel elements are more expensive solutions - in the long run, they generate significant expenses incurred by the user.

\section{Conclusion}

The solution, based on the applied LCC analysis, allows to reduce the costs of maintaining the steel structure in the scope of anti-corrosion protection, while maintaining certain construction safety standards. The considerations presented in the article confirm the long-term financial benefits for the user, resulting from the use of anti-corrosion protection in the form of a galvanized coating made in hot dip galvanizing technology, also justifying the use in practice - including in the steel structure design process, the LCC analysis. Its use allows to indicate the optimal solution in terms of the total lifecycle cost, taking into account initial outlays as well as costs incurred in the course of operation on the construction.

Limiting the use of volatile organic compounds applied to produce both the first protection and its subsequent repairs effectively reduces the need for paint products and the production of all types of solvents containing volatile organic compounds.

The use of galvanized coatings also significantly reduces the waste generated during the blasting of the steel material surface itself to be prepared for protection as well as subsequent wastes arising from the removal of rust and damaged paintwork from elements subjected to subsequent repair and renovation.

It can be therefore concluded that the method of anti-corrosive protection of steel components of engineering structures has a direct impact on the cost of their life cycle considered in the long-term perspective. 


\section{References}

[1] https://www.e-invest.pl/cynkowanie.html; last accessed 2017/12/15.

[2] D. Kowalski, Wpływ redukcji kosztów wykonania stalowych konstrukcji budowlanych na ich właściwości eksploatacyjne i ich przyszłe utrzymanie, (2007).

[3] E. Urbańska-Galewska, D. Kowalski, Dokumentacja projektowa konstrukcji stalowych w budowlanych przedsięwzięciach inwestycyjnych, Warszawa, Arkady (2015).

[4] D. Kowalski, Problems with anticorrosion coatings of bridge equipment element, Corrosion Protection, vol. 60, no. 3, pp. 65-68 (2017).

[5] D. Kowalski, Problemy z powłokami antykorozyjnymi na elementach wyposażenia obiektów mostowych, Ochrona. przed Korozja, vol. 60, no. 3, pp. 65-68 (2017).

[6] Dyrektywa 2001/81/WE Parlamentu Europejskiego i Rady z dnia 23 października 2001 r. w sprawie krajowych poziomów emisji dla niektórych rodzajów zanieczyszczeń powietrza Dz.U. UE 322.

[7] Dyrektywa 2004/42/WE Parlamentu Europejskiego i Rady z dnia 21 kwietnia 2004 r. w sprawie ograniczeń emisji lotnych związków organicznych $\mathrm{w}$ wyniku stosowania rozpuszczalników organicznych w niektórych farbach i lakierach oraz produktach do odnawiania pojazdów, a także zmieniająca dyrektywę 1999/13/WE.

[8] Rozporządzenia Ministra Rozwoju z dnia 8 sierpnia 2016 r. w sprawie ograniczania lotnych związków organicznych zawartych w niektórych farbach i lakierach przeznaczonych do malowania budynków i ich elementów wykończeniowych wyposażeniowych oraz związanych z budynkami i tym elementami konstrukcji oraz mieszaninach do odnawiania pojazdów, Dz. U. z 2016, poz. 1353.

[9] D. Kowalski, B Grzyl, A. Kristowski, The Cost Analysis of Corrosion Protection Solutions for Steel Components in Terms of the Object Life Cycle Cost, Civil and Environmental Engineering Reports 26.3, pp. 5-13 (2017).

[10]B. Grzyl, A. Kristowski, K. Jamroz, A. Gobis, Methods of estimating the cost of traffic safety equipment's life cycle. In MATEC Web of Conferences (Vol. 122, p. 02003), EDP Sciences, (2017).

[11] PN-EN 63300-3-3 Zarządzanie niezawodnością część 3-3: Przewodnik zastosowań. Szacowanie kosztu cyklu życia (2006). 